\title{
Determinants of Underpricing in Indonesian Stock Market
}

\author{
Tatang Ary Gumanti, Nurhayati, and Yeni Maulidia
}

\begin{abstract}
The purpose of this study is twofold. First, it examines the degree of underpricing in Indonesian initial public offering (IPO). Second, it examinesthe determinants of underpricing by focusing on three non-financial information, namely underwriter reputation, use of proceeds, and number of risk factors. Those three non-financial information serve as a signal concerning the quality of an IPO. A sample of 63 firms making IPO in Indonesian stock market from 2007 to 2012 is examined. The results show that Indonesian IPO firms on average are underpriced. Underwriter reputation has negative and significant relationship with the level of underpricing. Number of risk factorsis negatively related tothe degree of underpricing.
\end{abstract}

Index Terms - IPO underpricing, risk factors, underwriter reputation, use of proceeds.

\section{INTRODUCTION}

A firm always needs funds. One way to obtain funds is by going public, selling the stocks to the public known as initial public offerings (IPO). The funds raised from the issue are dedicated for a number of purposes, such as to strengthen capital base, business diversificationor to purchase another firm. All of the intended use of funds shall be stated in the issue prospectus.

To go public, a firm must publish a prospectus. Article 78 of the Indonesian's Law number 8 year 1995 about Capital Market states that prospectus must contain relevant and important information that will help prospective investors to adequately judge and analysis the firm. The prospectus must provide among others structure of ownership, use of proceeds from the IPO, summary of financial information, number of risk factors and other important information.

Determining the offering price of the stock is not easy both for the investors and the issuers. Investors must use various aspects in judging the offer price. The issuers have to cooperate with qualified underwriters to set up the offer price. If the offer is set up too low, issuers will be losing money, but if it is set up too high investors will not be interested in buying the stocks and the IPO could be unsuccessful.

Evidence across capital markets has shown that on average the IPO is underpriced. Underpricing is a condition where the offering price is lower than the closing price in the open market. The level of underpricing varies across capital markets and countries, but the emerging capital markets tend to be more underpriced than their counterparts of well-developed markets.

However, one argues that underpricing was deliberately done to attract uninformed investors [1]. One of the important

Manuscript received March 4, 2014; revised May 4, 2014.

The authors are with the Department of Management, Faculty of Economics, University of Jember Indonesia (e-mail: tatangag@yahoo.com, nur1963@yahoo.com,ye_chin@ymail.com). parties in going public process is underwriter, as it helps issuer to determine the offering price. Issuers will use prestigious underwriter in order to reduce uncertainty that cannot be disclosed in the prospectus [2]. Empirical studies, for example [3]-[5] generally confirm that the use of prestigious underwriter will lead to lower underpricing.

Apart from the reputation of underwriter, another variable that can be used as potential determinant of underpricing is number of risk factors [6]. The greater the ex-ante uncertainty, the greater is the expected variance (or standard error) of the stock's price in the period immediately following the issue [7]. Riskier stocks have greater price variance. The greater the ex-ante uncertainty, the greater is the expected compensation required by investors in order to ensure their participation in the IPO markets. Underpricing is a compensation paid to investor for the risk associated with the issue. Previous studies document that the number of risk listed in the prospectus is negatively related tothe level of underpricing, for example [8], [9].

The other potential determinant of underpricing is the use of proceeds from the IPO. Use of IPO proceeds for the purpose of repairing or strengthening working capital is suspected to have negative signal in the market. This is indicated by empirical evidence that on average firms that use IPO proceeds for repairing working capital exhibit higher initial return than firms that use IPO proceeds for investment [10], [11]. Leone et al. [12] suggest that IPOs providing specific use ofproceeds disclosures have lessex-ante uncertainty because these disclosures help investors predict the dispersion of secondary market values. This means that investors would consider the intended use of proceeds as a credible signal regarding the value of IPO. For example, if the funds raised from going public areused only for working capital improvement, investors would judge that the company does not have good qualification so the company is said to be exposed to higher risk and thus it shall have higher expected return.

This paper examines whether there is underpricingin Indonesian IPO market. It also examines whether underwriter reputation, the use of IPO proceeds, and number of risk factors affect the degree of underpricing in Indonesia stock market. The findings reveal that underpricing is negatively affected by underwriter reputation and by number of risk factors listed in the issue prospectus of the firms. Use of proceeds does not affect the degree of underpricing.

\section{LITERATURE REVIEW}

Underwriters play important role in the process of going public. Early study has shown that the selection of underwriter is critical in the success of the IPO. For example, prestigious underwriter can reduce investor uncertainty and their findings support the prediction of negative relationship 
between the prestige of underwriter and the degree of underpricing [2].This implies that low uncertainty will lead to low return, makes higher quality of underwriter lower underpricing.

In the case of firm commitment contract, underwriter will face absolute risk in the marketing the IPO. Thus, IPO firm wishing success shall be selective in appointing the underwriter. Prestigious underwriters is believed to have high reputationand accordingly is associated with lower level of underpricing, for example [3]-[5]. Although some studies find an inverse relation, see for example [13]-[15], the literature suggests that prestigious underwriter is associated with lower underpricing.

Accordingly, the following hypothesisis proposed:

$\mathrm{H}_{1}$ : underwriter reputation is negatively related to the degree of underpricing

By law, the prospectus must contain information on the use of proceeds from the IPO. There are a number of purposes of the use of proceeds, such as for capital expenditure, operating expenditure or paying debt as well as strengthening the firm's working capital. Previous studies document negative relationship between use of proceeds for investment and the level of IPO underpricing [16]-[10]. Yet, there is no clear theoretical explanation of how the use of proceeds will affect the level of underpricing given there are various reason behind the decision to go public.

Use of proceeds for operating expenditure especially for strengthening working capital is largely ignored as the potential for underpricing determinant. Gumanti [10], [11] suggest that the use of other variables instead of focusing on the use of proceeds for investment and expansion purposes in determining the level of underpricing. We might argue that when the funds raised in IPO are used for strengthening working capital, it means that the firm is focusing on making its operation safer. Investors may judge that the firm is risky as it keeps some of the proceeds for working capital purposes. When the firm is said to be risky, investors will demand higher return. Consequently, IPO firms that use some the funds from IPO for strengthening working capital will have larger initial returns as compensation for larger risk faced by the firms.

Accordingly, the following hypothesis is proposed:

$\mathrm{H}_{2}$ : Use of IPO proceeds is positively related to the level of underpricing

Other potential factor that can be used as the determinant of uncertainty of the offering price in IPO market is the number of risk factors provided in the prospectus. The higher the number of risks listed in the prospectus, the higher will be the level of underpricing [8]. Some studies document that the number of risks on prospectus is negatively related with initial return [8]-[17]. In contrast, others find a positive relationship between the numbers of risk and the level of underpricing [7]-[18].

Logically, the higher the number of risk factors listed in the prospectus the higher is the risk associated with the issuing firms, and thus the higher is the expected return of the share demanded by the investors. This assertion is supported by [11] who report that the number of risk factor listed in the issue prospectus is positively related to underpricing for firms making IPO in Indonesian capital market from 1990 to 2005. This reason leads to the following hypothesis.
$\mathrm{H}_{3}$ : Number of risk factors listed in the prospectus is positively related to underpricing

\section{RESEARCH METHODS}

This study analyzes whether underwriter reputation, use of proceeds for working capital, number of risk factors affect the degree of underpricing in Indonesian stock market from 2007 to 2012. Compared to [9]-[18], the current study employs more recent data.

The population of this study is all companies making IPO at the Indonesian stock market from 2007 to 2012. Samples are determined with the following criteria. First, the prospectus is available in the database of Faculty of Economics University of Jember. Second, company has complete data through use of proceeds, underwriter information and risk information.

The following model for testing the hypotheses is used.

$$
\mathrm{IR}=a+b \mathrm{UR}+d \mathrm{RF}+e
$$

where IR is initial return, UR is underwriter reputation, UP is use of IPO proceeds, and RF is number of risk factor.

Initial return is measured as the difference between the first day closing price and the offering price expressed in terms of percentage. The underwriter reputation is a dummy variable. The prestige of underwriter is determined following [2] who classify it based on the frequency of the underwriter being the lead underwriter, i.e. if it has been assigned as lead underwriter of at least eight times, it is categorized as prestigious underwriter and it has value of 1 and 0 for otherwise. Following [16], this research uses dummy variable for the use of proceeds from IPO. Value of 1 is given if there is a part of the proceeds being used for working capital, and 0 for otherwise. Number of risk factor is measured using the total risk factors listed in the issue prospectus.

\section{FINDINGS AND DISCUSSION}

A total of 109 firms making IPO during 2007-2012 at the Indonesian Stock Exchange. As shown in Table I, a final sample comprises of 63 IPOs.

TABLE I: SAMPLE SELECTION PROCESS

\begin{tabular}{lc}
\hline \hline \multicolumn{1}{c}{ Notes } & $\begin{array}{c}\text { Number } \\
\text { of Firm }\end{array}$ \\
\hline $\begin{array}{l}\text { Firm making IPO in May 2007-December 2012 } \\
\text { The firm's prospectus is not available in the database of }\end{array}$ & $\begin{array}{c}109 \\
\text { Faculty of Economics University of Jember }\end{array}$ \\
$\begin{array}{l}\text { Firm with prospectus available in the database of Faculty } \\
\text { of Economics University of Jember }\end{array}$ & 65 \\
$\begin{array}{l}\text { The prospectus is incomplete } \\
\text { Final sample }\end{array}$ & 2 \\
\hline \hline
\end{tabular}

Description of the sample firms by year of going publicand industrial sector is shown in Table II. Panel A of Table II shows the distribution of sample by years and panel B presents the distribution of sample by industry classification (sector). Year 2007 has the largest IPO firms of 19, whilst year 2009 has the lowest with only two firms meeting the sampling criteria. Infrastructure, utilities and transportation sector has the largest number of firms, of which there are 14 
firms, whilst sector with the lowest representative is consumer goods industry with only one firm.

TABLE II: DISTRIBUTION OF SAMPLE BY YEAR AND INDUSTRY CLASSIFICATION

\begin{tabular}{lccc}
\hline \multicolumn{4}{c}{ CLASSIFICATION } \\
Description & $\begin{array}{c}\text { Total } \\
\text { IPO }\end{array}$ & $\begin{array}{c}\text { Selected } \\
\text { IPO }\end{array}$ & $\%$ \\
\hline Panel A : Based on IPO years & & & \\
2007 & 22 & 19 & 86.36 \\
2008 & 19 & 13 & 68.42 \\
2009 & 13 & 2 & 15.38 \\
2010 & 23 & 9 & 39.13 \\
2011 & 25 & 14 & 56.00 \\
2012 & 7 & 6 & 85.71 \\
\hline $2007-2012$ & 109 & 63 & 57.80 \\
\hline Panel B : Based on Industry Classification & 6 & & \\
Agriculture & 16 & 11 & 100.00 \\
Mining & 8 & 3 & 68.75 \\
Basic Industry and Chemicals & 3 & 2 & 66.50 \\
Miscellaneous Industry & 3 & 1 & 33.33 \\
Consumer Goods Industry & 19 & 8 & 42.11 \\
Property, Real Estate and Building & & & \\
Construction & 20 & 14 & 70.00 \\
Infrastructure, Utilities \& & & & \\
Transportation & 13 & 9 & 69.23 \\
Finance & 21 & 9 & 43.86 \\
Trade, Services \& Investment & 109 & 63 & 57.80 \\
\hline Total & & & \\
\hline \hline
\end{tabular}

Table III presents the level of initial returns based on year of IPO and industry classification. As can be seen in Table III, year 2007 is known to have the largest initial returns, whilst year 2011 is recorded as the year with the lowest initial returns. Looking at the industry classification, the property, real estate and building construction has the highest initial returns, whilst agriculture has the lowest initial returns. The evidence shown in Table III confirms that Indonesia IPOs are on average underpriced as much as 25.32 percent.

TABLE III: DESCRIPTIVE STATISTICS OF INITIAL RETURNS BASED ON YEARS AND INDUSTRY CLASSIFICATION

\begin{tabular}{|c|c|c|c|c|}
\hline Description & $\mathrm{N}$ & Mean & Min. & Max. \\
\hline \multicolumn{5}{|l|}{ Panel A : Based on IPO years } \\
\hline 2007 & 19 & $0.4094 * * *$ & -0.19 & 1.58 \\
\hline 2008 & 13 & $0.2608 *$ & -0.82 & 1.79 \\
\hline 2009 & 2 & $0.3000^{* * * *}$ & 0.02 & 0.04 \\
\hline 2010 & 9 & $0.2844 * * *$ & -0.07 & 0.68 \\
\hline 2011 & 14 & $0.1015^{* *}$ & -0.17 & 0.50 \\
\hline 2012 & 6 & $0.2238 * *$ & 0.01 & 0.68 \\
\hline Total & 63 & $0.2532 * * *$ & -0.82 & 1.79 \\
\hline \multicolumn{5}{|c|}{ Panel B : Based on Industry Classification } \\
\hline Agriculture & 6 & $0.1517 * *$ & -0.01 & 0.37 \\
\hline Mining & 11 & $0.2327 * *$ & -0.38 & 0.70 \\
\hline Basic Industry and Chemicals & 3 & $0.4133^{*}$ & 0.06 & 0.69 \\
\hline Miscellaneous Industry & 2 & $0.1600 * *$ & 0.15 & 0.17 \\
\hline Consumer Goods Industry & 1 & $0.1700 * * *$ & 0.17 & 0.17 \\
\hline $\begin{array}{l}\text { Property, Real Estate and } \\
\text { Building Construction }\end{array}$ & 8 & $0.4800^{* * * *}$ & -0.17 & 1.79 \\
\hline $\begin{array}{l}\text { Infrastructure, Utilities \& } \\
\text { Transportation }\end{array}$ & 14 & 0.2221 & -0.82 & 1.58 \\
\hline Finance & 9 & $0.3211^{* * *} *$ & 0.02 & 0.77 \\
\hline Trade, Services \& Investment & 9 & $0.1611 * * *$ & -0.01 & 0.50 \\
\hline Total & 63 & $0.2532 * * *$ & -0.82 & 1.79 \\
\hline
\end{tabular}

Notes: $* * *, * *$, and $*$ denote significant at $1 \%, 5 \%$, and $10 \%$, respectively.

The descriptive statistics of initial return and number of risk factors is shown in Table IV. The average initial return is 25.3 percent and significantly different from zero $(p<0.01)$. It means that the sample firms experience significant underpricing. The level ofunderpricing found here is greater than the figure reported in [11] who documentan average underpricing of 22.89 percent in Indonesian firms making
IPO from 1990-2005. The minimum of initial return is -82.00 percent, and the maximum is 179.00 percent, whilst [18] report a minimum of 32.56 percent and a maximum of 480.00 percent. Evidence of significant underpricing reported here is in support of worldwide phenomenon that on average IPO is underpriced.

TABLE IV: DESCRIPTIVE STATISTICS OF VARIABLES

\begin{tabular}{llllll}
\hline \hline Variable & Mean & Median & Std. Dev. & Minimum & Maximum \\
\hline INT & 0.253 & 0.1512 & 0.403 & -0.820 & 1.790 \\
RISK & 21.51 & 17 & 14.396 & 4 & 63 \\
\hline \hline
\end{tabular}

The number of risk factors ranges from the lowest of 4 to the highest of 63 . This figures are slightly different compared to [11] who report a range of 1 to 40 of risk factors listed in the prospectus. Table IV shows that on average the number of risk factors is 21.51 which may be regarded that the risk associated with the business is large as there are more than 21 risk factors provided in the prospectus.

Not reported in Table IV, 31 firms or 49.20 percent employ non prestigious underwriter, whilst 32 firms or 50.80 percent are underwritten by prestigious underwriter. Looking at the use of proceeds from the IPO, there are 17 firms or 26.98 percent use part of the funds generated from IPO for improving or strengthening working capital. This means that 46 firms or 73.02 percent of the sample firms do not use the fund generated from IPO for improving their working capital. In other words, the firms may use the funds for more productive activities.

Table $\mathrm{V}$ presents the matrix correlation for all variables examined in this study. Underwriter reputation and number of risk factors are negatively and significantly correlated with initial return, whilst use of proceeds has negative but insignificant correlation with initial return.

TABLE V: MATRIX CORRELATION OF THE VARIABLES

\begin{tabular}{lccc}
\hline \hline \multicolumn{1}{c}{ Variable } & $\begin{array}{c}\text { Underwriter } \\
\text { Reputation }\end{array}$ & $\begin{array}{c}\text { Use of } \\
\text { Proceeds }\end{array}$ & $\begin{array}{c}\text { Number of } \\
\text { Risk Factors }\end{array}$ \\
\hline Initial Return & $-0.290^{* *}$ & -0.090 & $-0.332^{* *}$ \\
Underwriter & - & 0.117 & $0.276^{* *}$ \\
Reputation & - & - & 0.190 \\
Use of Proceeds & - & & \\
\hline
\end{tabular}

Note: **significant at $5 \%$

TABLE VI: RESULTS OF MULTIPLE LINEAR REGRESSION

\begin{tabular}{llrl} 
Variable & Prediction & Coefficients & \multicolumn{1}{c}{$\mathrm{t}_{\text {stat. }}$} \\
\hline UR & Negative & -0.192 & $-1.706^{* *}$ \\
UP & Positive & -0.011 & -0.110 \\
RF & Positive & -0.008 & $-2.139 * *$ \\
\hline \hline
\end{tabular}

Note: $* *$ significant at $5 \%$,UR is underwriter reputation, UP is use of IPO proceeds, and RF is number of risk factors.

The results of multiple linear regression analysis are shown in Table VI. The results show that underwriter reputation is negatively related to underpricing $(p<0.05)$. This finding supports previous results, for example [3]-[5]. Thus, it is confirmed that prestigious underwriter is seen to be related with high quality and large IPO for which we might argue that good and large firms will have lower risk and they prefer to select prestigious underwriter which lead to lower 
initial return. In other words, the choice of underwriter is important, because prestigious underwriter will be able to provide better service and analysis and relates to lower underpricing [2].

The study finds that use of proceeds does not affect the level of underpricing. The sign of the coefficient is negative, which is in contrast to the expectation. This means that regardless of the use of proceeds from the IPO, investors may consider that the information is not significant in determining their selection of IPO firm.

Startup firm is associated with high risk, and high risk relates with high level of underpricing. Firm making IPO should disclose information related to the use of funds generated from IPO (proceeds), if the use of proceeds is focused on improving working capital, the company is said to be risk averse and it might not be in the investor's expectation that usually expect the funds raised in IPO to be used for productive activities. Gumanti and Abdul Mann an [11] document negative and significant relation between use of proceeds and underpricing. Yet, the current study uses different measurement compared to [11]. They consider the use of proceeds for investment and expansion where the coefficient is predicted to be negative given that allocating most of the funds for investment or expansion is less risky and report that lower value of underpricing. They argue that firm is willing to use most of the funds for investment and expansion only when it has strong financial condition. Interestingly, [19] found that the use of proceeds for financing purposes have smaller underpricing than the use for operation and investment. This conflicting finding offers us for further examination given that the results reported in this study may be driven by the selection bias as in this study the minimum portion of funds used for working capital purposes is not determined using certain level of percentage.

This study documents negative relationship between number of risk factors and the level of underpricing. The result of this study supports [8] and [17] who document negative relation between the level of underpricing and number of risk factors. The result is in contrast with [7]-[20] who found positive relation.

As mandated by regulation, issuers have to disclose companies risk information in the prospectus. Underpricing should be higher when firms disclose more information to compensate for higher risk borne by investors who bought the stocks. Yet, this study reports opposite direction, that is firms disclose more number of risk are less underpriced. This finding does not support [11] who report positive relationship between number of risk factors and the level of underpricing. This different finding could be attributed to the characteristics of firms being examined. The current study uses more recent data, i.e., 2007-2012, whilst [11] use considerably older data, i.e., 1990-2005. We might also argue that the Indonesian capital market law was in effect in 1995 with many regulations following it. Gumanti and Abdul Mannan [11] do not divide their sample firms to look whether the enactment of capital market law affects the content and number of risk listed in the issue prospectus. Thus, elaboration on this issue may provide better explanation of the phenomenon.

\section{CONCLUSION}

This research examines the effect of underwriter reputation, use of proceeds, and number of risk factors on the degree of underpricing in Indonesian stock market for the years2007-2012. The study documents that underwriter reputation and number of risk factors has negative and significant relationship with underpricing. Use of proceeds has negative but insignificant relationship with underpricing.

Three limitations are identified in this study. Firstly, this research does not account for the effect of global economic crisis in year 2008 where Indonesia was among the countries that are severely hit. The crisis has led the stock market to plummet more than half of the previous figure. Accordingly, this period is said to be risky that may expose issuing firm to a larger risk than in the other periods which may affect the risk preference of the investors making investors are less rational in their buy or sell decision in the IPO market. Thus, future study may look at specific periods, especially the study may differentiate between the periods where there are no economic or financial crisis and when there are the crisis.

Secondly, this study does not group the number of risk factors based on the type of business or industry classification. We might argue that certain industry may be exposed to higher risk than other industries. Thus, future study may differentiate the samples based on industry classification. Lastly, we might argue that the difference of the result may be affected by the selection of proxy or measurement where this study uses dummy variable in measuring the use of proceeds of the IPO based on the use for strengthening working capital. So, future study is recommended to use the other measurements, for example use of proceeds variable is calculated by the percentage of total proceeds as a portion of for working capital.

\section{REFERENCES}

[1] K. Rock, "Why new issues are underpriced," Journal of Financial Economics, vol. 15, pp. 187-212, 1986.

[2] R. Carter and S. Manaster, "Initial public offerings and underwriter reputation," Journal of Finance, vol. 45, pp. 121-135, 1990.

[3] J. R. Booth, C. Booth, and D. Deli, "Choice of underwriters in initial public offerings," Journal of Business and Policy Research, vol. 5, pp. 131-158, 2010.

[4] S. K. Sharma and A. Seraphim, "IPO underpricing phenomenon and the underwriter's reputation," The Romanian Economic Journal, vol. 38, pp. 181-209, 2010.

[5] L. Yang, "An Analysis of the IPO underpricing for high-tech companies in Japan,” M. A. thesis, Saint Mary's University, 2012.

[6] R. P. Beatty and J. T. Ritter, "Investment banking, reputation, and the underpricing of initial public offerings," Journal of Financial Economics, vol. 15, pp. 213-232, 1986.

[7] C. Laurin, "Uncertainty and the underpricing of share issue privatisations," Ph.D. dissertation, Université du Québec à Montréal Canada, 1997.

[8] P. M. Clarkson, "The underpricing of initial public offerings, ex ante uncertainty, and proxy selection," Accounting and Finance, vol. 34, pp. 67-78, 1994

[9] T. A. Gumanti, "Accounting information and the underpricing of Indonesian initial public offerings," Ph.D. dissertation, School of Economics and Finance, Edith Cowan University, WA, 2000.

[10] T. A. Gumanti, "Ownership retention, jumlahfaktorrisiko, tujuanpenggunaandanadan underpricing di pasarperdanasaham," presented at the First PPM National Conference on Management Research 'Management in Globalization Era', Jakarta-Indonesia, November, pp. 22-23, 2007.

[11] T. A. Gumanti and S. S. A. Mannan, "Number of risk factors and underpricing: A case of Indonesian initial public offerings," presented at the International Seminar on Business, Management, and 
Environment: A Comprehensive Study in Asian Economy, Bali-Indonesia, October 29-30, 2013.

[12] A. J. Leone, S. Rock, and M. Willenborg, "Disclosure of intended use of proceeds and underpricing in initial public offerings," Journal of Accounting Research, vol. 45, pp. 111-153, 2007.

[13] R. P. Beatty and I. Welch, "Issuer expenses and legal liability in initial public offerings," Journal of Law and Economics, vol. 39, pp. 545-602, 1996.

[14] T. Loughran and J. R. Ritter, "Why has IPO underpricing increased over time?" Journal of Financial Management, vol. 33, pp. 5-37, 2004

[15] J. W. Cooney, A. K. Singh, R. B. Carter, and F. H. Dark, "The IPO partial-adjustment phenomenon and underwriter reputation," Working paper, Kansas State University, 1999.

[16] J. B. Kim, I. Krinsky, and J. Lee, "Motives for going public and underpricing: New findings from Korea," Journal of Business Finance and Accounting, vol. 20, pp. 195-211, 1993.

[17] D. A. Hensler, R. C. Rutherford, and T. M. Springer, "The survival of initial public offerings in the aftermarket," Journal of Finance Research, vol. 20, pp. 93-110, 1997.

[18] T. A. Gumanti and M. N. Niagara, "Ownership retention, number of risk factors and underpricing in Indonesian initial public offerings" presented at Indonesian Accounting National Symposium (SNA) IX, Padang-Indonesia, August, 12-14, 2006.

[19] P. M. Clarkson and J. Merkley. "Ex ante uncertainty and the underpricing of initial public offerings: Further Canadian Evidence," Canadian Journal of Administrative Sciences, vol. 11, pp. 54-67, 1994

[20] J. C. Spindler, "IPO underpricing, disclosure, and litigation risk," Research paper, no. C09-9, 2010.

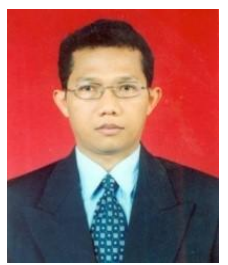

Tatang Ary Gumanti was born in Jember-Indonesia, on November 25, 1966. In 1989, he obtained his bachelor degree from Department of Management, Faculty of Economics, University of Jember, Indonesia. His master degree in Business Accounting in 1996 and doctorate degree in Finance in 2000 were granted by Faculty of Business Edith Cowan university, Perth-Western Australia. His research interest is in the area of corporate finance and positive accounting theory.

Dr. Gumanti currently is lecturer at the Department of management faculty of Economics University of Jember, East Java, Indonesia. He has published a number of papers in the area of corporate finance, in particular relating to topic on price efficiency and earnings management in Initial Public Offering. He has published three books, namely ManajemenInvestasi: Konsep, TeoridanAplikasi (buku 1) (2007), ManajemenInvestasi: Konsep, TeoridanAplikasi (2011), and Kebijakan Dividen: Teori, Empiris danImplikasi (2013). Dr. Gumanti is a member of Indonesian economic graduate association (ISEI) and a referee in a number of Indonesian accredited journals.

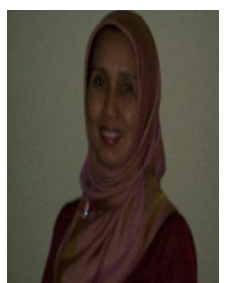

Nurhayati was born in Jember, Indonesia on June 7, 1963. In 1984, she obtained her bachelor degree in management from the Department of Management, Faculty of Economics, University of Jember, Indonesia. She was awarded a doctorate degree from Airlangga University, Indonesia in 2004 with major in financial management study. Dr. Nurhayati is a senior lecturer at the Department of Management, Faculty of Economics, University of Jember.

Dr. Nurhayati has published a number of paper in the area of financial management and strategic management in Indonesian Journals.

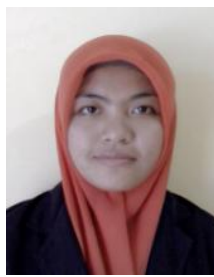

Yeni Maulidia was born in Jember on September 24, 1991. Ms Yeni has just graduated from bachelor degree at the Department of Management, Faculty of Economics, University of Jember in 2013. Ms Maulidia currently serves as a research assistant. 